\title{
ANALISIS KOMPOSISI DALAM CERPEN "PENGANTAR TIDUR PANJANG" KARYA EKA KURNIAWAN: KAJIAN MORFOLOGI
}

\section{COMPOSITION IN SHORT STORY OF "PENGANTAR TIDUR PANJANG" BY EKA KURNIAWAN: MORPHOLOGY STUDY}

\author{
Rengki Afria, Olivia Virginia \\ Universitas Jambi \\ Ponsel: 085266506340; Pos-el: rengkiafria@gmail.com; tanolivia6@gmail.com
}

\begin{abstract}
Abstrak
Penelitian ini bertujuan mendeskripsikan komposisi dalam cerita pendek "Pengantar Tidur Panjang Karya Eka Kurniawan: Kajian Morfologi”. Teori yang digunakan adalah morfologi. Metode yang digunakan dalam penelitian ini adalah metode deskriptif kualitatif. Sumber data yang digunakan adalah bentuk komposisi dalam cerita pendek "Pengantar Tidur Panjang" Karya Eka Kurniawan. Metode pengumpulan data yang digunakan adalah metode catat. Metode analisis data, yakni metode distribusional. Hasil penelitian ditemukan dua bentuk komposisi, yakni komposisi eksosentris dan endosentris. Hasil analisis disimpulkan bahwa terdapat 23 data yang mengandung unsur komposisi. Unsur tersebut didapatkan 10 data yang bersifat eksosentris dan 13 data yang bersifat endosentris.
\end{abstract}

Kata Kunci: komposisi; cerita pendek; morfologi

\begin{abstract}
This study aims to describe the composition of the short story "Pengantar Tidur Panjang: Kajian Morfologi" written by Eka Kurniawan. The theory used is morphology. The method used in this research is descriptive qualitative method. The data source used is the composition form in the short story "Pengantar Tidur Panjang" by Eka Kurniawan. The data collection is conducted through reading and note-taking method. Then, the data is analyzed by using distribution method. The results of the study show that there two forms of composition, namely exocentric and endocentric compositions. It is concluded that there are 23 data containing elements of composition. Out of those elements, 10 data are exocentric and 13 data are endocentric.
\end{abstract}

Keywords: composition; exocentric; endocentric; morphology 


\section{Pendahuluan}

Salah satu proses pembentukan kata atau susunan bentuk kata dalam kajian morfologi adalah komposisi. Komposisi merupakan bentuk gabungan dua kata atau lebih yang memiliki makna kata yang utuh (Verhaar, 2010; Mulyono, 2013). Komposisi adalah hasil penggabungan antara satu morfem bebas dengan morfem bebas yang satunya, yang tidak lagi mengandung makna dari salah satu morfem yang menyusunnya, melainkan menghasilkan kontruksi makna baru, yang bercirikan ketaktersisipan, ketakterluasan, dan ketakterbalikan. Proses komposisi (pemajemukan) sebagai proses penggabungan dua kata yang mengandung pengertian tertentu. Pengertiannya tidak menonjolkan makna setiap kata, tetapi membentuk suatu makna baru secara bersama-sama.

Bentuk-bentuk komposisi tersebut dapat ditemukan dalam berbagai suasana komunikasi, baik dalam bentuk lisan, maupun tulisan. Bentuk tulisan yang dijadikan sebagai objek kajian dalam penelitian ini adalah cerpen. Di dalam cerpen tentu saja mengandung kata yang berbentuk morfem sebagai bagian proses morfologis. Pengkajian mengenai sebuah karya sastra seperti cerpen ini, sering kali menjadi sebuah masalah tersendiri disebabkan ketidaktahuan pembaca mengenai macam-macam proses morfologis, salah satunya yang paling sering dijumpai dalam berbagai bacaan ilmiah, karangan bebas, peristilahan, dan kata yang sering tuturkan sendiri baik secara langsung maupun tidak langsung, adalah proses morfologis komposisi atau pemajemukan kata.

Maka, dihadirkan unsur-unsur kata yang mengandung komposisi atau pemajemukan kata, sebagai bentuk dari gabungan antara dua kata (atau lebih) menjadi satu makna yang baru. Objek penelitian yang digunakan adalah cerita pendek "Pengantar Tidur Panjang" karya Eka Kurniawan. Tujuan penelitian ini untuk mendeskripsikan unsur-unsur atau bagian-bagian dari proses morfologis komposisi yang terdapat di dalam cerpen "Pengantar Tidur Panjang" karya Eka Kurniawan. Cerpen ini dipilih didasarkan pada beberapa pertimbangan, yakni memiliki ragam kosakata memuat diksi-diksi karya sastra yang mengandung bentuk kata dan frasa yang tergolong dalam komposisi yang memadai.

Penelitian terdahulu yang menjadi relevansi pada penelitian ini, 
yakni; Octarini et al. (2017) dengan judul Proses Pembentukan Kata dalam Kumpulan Cerpen 1 Perempuan 14 Laki-Laki Karya Djenar Maesa Ayu. Hasil penelitiannya disimpulkan bahwa dalam kumpulan cerpen 1P14LK terdapat afiksasi, reduplikasi, dan komposisi. Afiksasi terdiri atas prefiks, infiks, sufiks, konfiks, dan simulfiks yang memiliki bentuk, fumgsi, dan makna yang berbeda. Reduplikasi terdiri atas reduplikasi morfemis. Reduplikasi morfemis terdiri atasdua macam, yaitu reduplikasi akar dan reduplikasi berafiks. Selain itu, juga terdapat komposisi nominal. Komposisi nominal terdiri atas komposisi nominal bermakna gramatikal dan komposisi nominal bermakna idiomatik.

Berikutnya adalah "Proses Morfologis dalam Bahasa Melayu Dialek Pontianak" oleh Fauziah (2018). Hasilnya adalah Afiks dalam BMDP terdapat tiga macam yaitu prefiks, sufiks dan konfiks. Afiks dalam bentuk prefiks yang ditemukan ada tujuh yaitu; [ber], [di], [ke], [me], [pe], [te] [se]. Reduplikasi dalam BMDP terdapat tiga macam, yakni reduplikasi keseluruhan, reduplikasi berkombinasi dengan afiks dan reduplikasi dengan perubahan fonem.

Seterusnya, Putri meneliti tentang kata majemuk nomina dalam koran Kougaku, edisi 1, Juni 2011. Hasil penelitian ini diketahui bahwa kata majemuk nomina bahasa Jepang dapat terbentuk dari komposisi berupa nomina + nomina, verba + nomina, adjektiva + nomina, nomina + verba yang dinominalkan, dan verba + verba yang dinominalkan. Jenis makna idiomatik kata majemuk nomina bahasa Jepang terdiri atas makna idiom, makna semi-idiom, dan makna nonidiom.

Lebih lanjut, Simpen (2017) menulis tentang Dinamika Pembentukan Kata Bahasa Indonesia. Hasil penelitian tersebut menunjukkan bahwa dari beberapa pembentukan kata ini, tidak semua dianalisis tetapi hanya dikhususkan pada pembentukan kata yang dinamis (mengalami pasang surut). Hasil pengkajian membuktikan bahwa pembentukan kata dalam bahasa Indonesia dewasa ini, senantiasa mengalami dinamika. Kecenderungan dinamika mengarah pada munculnya afiks asing atau afiks bahasa serumpun, penanggalan afiks, munculnya leksikal baru, dan menyusutnya pemakaian kata 
yang sebelumnya sangat tinggi. Di sisi lain, ada kecenderungan bahwa morfem unik berubah menjadi morfem bebas. Kajian ini ditulis juga oleh Kusumawardhani (2015) dengan judul the Analysis of Morphology in Writing an English Narrative Composition.

Terakhir, Fauziyah

(2020)

meneliti tentang "Kata Majemuk Dalam Teks Berita Daring Cnn International Edisi September 2019: Kajian Morfologi”. Hasil penelitian dijelaskan proses compounding dalam teks berita daring CNN International, edisi Sepember 2019 dapat diklasifikasikan pada dua bentuk yang terdiri atas bentuk tulisan dan bentuk kata majemuk. Berdasarkan bentuk tulisan didapati dua bentuk tulisan yaitu close form (bentuk tertup) dan open form (bentuk terbuka), kemudian berdasarkan bentuk kata mejemuknya didapati dua bentuk, yaitu berbentuk endocentic compound (memiliki inti kata) dan excocentric compound (tidak memiliki inti kata). Kategori kata dalam teks berita daring CNN International edisi Sepember 2019, didapati dua katgori kata majemuk, yaitu kata majemuk yang berkategori nomina (nomina + nomina/verba + nomina) dan kata majemuk yang berkategori verba (nomina+verba).

Penelitian terdahulu yang telah disebutkan dalam kajian proses morfologis secara variatif. Perbedaan dan persamaan dengan penelitian ini terletak pada teori, metode yang digunakan, sementara hasil nantinya berbeda dari segi objek kajiannya.

\section{Landasan Teori}

\subsection{Kajian Morfologi dan Proses Morfologis}

Secara etimologis, menurut Chaer (2008), istilah morfologi dalam bahasa Indonesia berasal dari kata morphology dalam bahasa Inggris. Istilah tersebut terbentuk dari dua morfem, yaitu morph yang berarti 'bentuk' dan logy yang berarti 'ilmu'. Chaer (2008) juga menjelaskan, mengenai rangkaian kerja menganalisis objek morfologi, yaitu mengenalisis unsur-unsur bahasa, dan alat-alat analisis terjadinya pembentukan kata. Tahap - tahap kajiannya yaitu sebagai berikut; (1) Unsur bahasa yang dianalisis mencakup morfem dasar, morfem terikat, dan kata, (2) Alat analisis pembentukan kata menggunakan peranti, yaitu bentuk dasar, dan alat pembentukan kata itu sendiri seperti bentuk dasar, alat 
pembentuk kata (afiksasi, reduplikasi, komposisi, morfofonemik, infleksi, dan derivasi), (3) Makna gramatikal dari sebuah kata akibat proses pembentukan kata, dari suatu bentuk ke bentuk lain.

Kajian morfologi biasanya dibedakan dengan adanya beberapa morfem berdasarkan kriteria tertentu, di antaranya morfem terikat dan morfem bebas. Morfem bebas adalah morfem yang tanpa kehadiran morfem lain dapat muncul dalam ujaran. Misalnya, dalam bahasa Indonesia bentuk; pukul, ambil, potong, dan gali termasuk dalam morfem bebas.

Morfem-morfem tersebut dapat digunakan tanpa morfem lain. Sebaliknya, yang dimaksud dengan morfem terikat adalah morfem yang tanpa digabung dulu dengan morfen lain, tidak dapat muncul dalam ujaran. Semua imbuhan (afiks) dalam bahasa Indonesia adalah morfem terikat. Morfologi menjadi penting dalam pembelajaran bahasa, karena memiliki peran penting dalam pembentukan morfem sebagai dasar pembentukan frase, klausa, kalimat, paragraf, serta wacana (Rohmadi, 2012).

Jadi, secara harfiah kata morfologi berarti ilmu mengenai bentuk atau dapat juga dikatakan sebagai ilmu yang mempelajari bentuk - bentuk bahasa atau kata.

Seperti yang sudah dijelaskan sebelumnya, bahwa salah satu kajian dari morfologi adalah pembentukan kata, atau proses morfologis itu sendiri. Ramlan (2001) menjelaskan bahwa proses morfologis adalah proses pembentukan katakata, dari satuan lain yang merupakan bentuk dasarnya.

\subsection{Komposisi}

Komposisi merupakan suatu proses morfemis yang menggabungkan dua morfem dasar atau pradasar menjadi satu kata yang disebut "kata majemuk" atau "compound" (Verhaar, 2010). Selanjutnya, Mulyono menyatakan bahwa komposisi adalah proses penggabungan dua kata atau penggabungan dua pokok kata yang membentuk kata. Berdasarkan jenis dan unsur-unsurnya, kata majemuk memiliki beragam kategori di antaranya: kata majemuk berkategori nomina, kata majemuk berkategori verba, kata majemuk berkategori adjektiva, dan sebagainya.

Kata majemuk atau kompasitum dapat diungkapkan sebagai gabungan dari dua kata, atau lebih yang membentuk satu kesatuan arti. Unsurunsur yang menjadi dasar pembentukan 
kata majemuk, akan hilang hakekat kekataannya karena strukturmya berada dalam kesatuan gabungan itu, dan hakekat kata majemuk akan hancur pula jika disisipkan suatu kata ditengahnya.

Lebih lanjut, Keraf (dalam Basyarudin, 2015) membedakan kata majemuk yang bersifat eksosentris (tidak mengandung unsur inti), misalnya: lakibini, tuamuda, hancurlebur; dan kata majemuk endosentris (ada dua unsur yang menjadi inti gabungan), misalnya : saputangan, orangtua (intinya sapu dan orang).

Sejalan itu, Ramlan (2001) menyatakan bahwa kata majemuk adalah kata yang terdiri atas dua kata sebagai unsurnya. Selain itu, ada juga kata majemuk yang terdiri atas satu kata dan satu pokok kata sebagai unsurnya, dan ada pula yang terdiri atas pokok kata semua. Proses pemajemukan adalah peristiwa bergabungnya dua morfem dasar, atau lebih secara padu dan menimbulkan arti yang relatif baru. Ramlan menyebutkan ada dua ciri - ciri kata majemuk. Pertama, salah satu atau semua unsurnya berupa pokok kata.
Kedua, unsur-unsurnya tidak mungkin dipisahkan atau tidak mungkin diubah strukturnya. Berdasarkan berbagai teori ahli linguistik tersebut, dapat dirangkum bahwa komposisi atau pemajemukan adalah proses morfem yang menggabungkan dua morfem dasar menjadi satu kata.

\section{Metode Penelitian}

Metode yang digunakan adalah Metode kualitatif dengan pendekatan deskriptif (baca Mahsun, 2012). Data disajikan dalam bentuk kata-kata. Data berupa bentuk komposisi yang bersumber dari kata dan frasa dalam cerita pendek "Pengantar Tidur Panjang" karya Eka Kurniawan.

Metode pengumpulan data yang digunakan adalah metode catat dan baca. Metode catat dan baca dilakukan dengan membaca cerpen kemudian mencatat data yang berhubungan dengan komposisi.

Analisis data menggunakan metode distribusional (baca Sudaryanto, 2015). Distribusi tersebut dengan mengklasifikasikan, transkripsi, dan pemaknaan. 


\section{Hasil dan Pembahasan}

Hasil dari data yang diklasifikasikan oleh penulis dengan menggunakan teori dari Gorys Keraf adalah sebagai berikut.

\subsection{Sifat Eksosentris}

Komposisi atau kata majemuk yang bersifat eksosentris, yaitu komposisi atau kata majemuk yang tidak mengandung unsur inti, tidak ada satu unsur pun pada kata pertama yang dapat menjelaskan ataupun menggantikan keberadaan unsur lainnya atau kata kedua, begitu pula sebaliknya. Maka, data yang telah diklasifikasikan dalam tabel di atas yang memiliki sifat eksosentris adalah sebagai berikut.

a) Adik Kelas

Komposisi atau kata majemuk dari kata adik kelas terdiri atas dua kata, kata adik memiliki arti saudara kandung, kerabat, atau sapaan kepada laki-laki ataupun perempuan yang lebih muda (Depdiknas, 2012). Sedangkan, kata kelas memiliki arti tingkatan ataupun tempat untuk belajar disekolah, bisa juga diartikan sebagai sekelompok masyarakat atau sebuah golongan yang diurutkan berdasarkan jenjang pendidikannya, penghasilannya, dan lain sebagainya, atau persamaannya dalam berbagai sifat juga bisa.
Maka, ketika kata adik dan kata kelas dilekatkan menjadi suatu komposisi atau kata majemuk, ia memiliki arti sebagai sebutan bagi laki-laki atau perempuan yang lebih muda, dalam lingkup pendidikan.

Kata adik kelas masuk ke dalam sifat eksosentris dan tidak masuk ke dalam sifat endosentris disebabkan kedua kata tersebut tidak ada kata yang unsurnya menerangkan ataupun diterangkan. Kata adik kelas hanyalah sebagai sebutan atau pengganti seperti penjelasan yang telah dijelaskan sebelumnya.

b) Earphone

Komposisi atau kata majemuk earphone terdiri atas dua kata, yaitu kata ear yang berarti dalam bahasa Indonesia adalah telinga, merupakan suatu organ bagian tubuh makhluk hidup yang digunakan untuk mendengar (Depdiknas, 2012) Sementara, kata phone yang dalam bahasa Indonesia berarti gawai atau ponsel pintar merupakan suatu alat canggih yang digunakan untuk berkomunikasi dengan mudah dan membantu melakukan banyak kegiatan sehari-hari lainnya dengan mudah pula; piranti elektronik atau mekanik dengan fungsi praktis; 
gadget (Depdiknas, 2012). Maka, komposisi atau kata majemuk earphone dapat diartikan sebagai sebuah alat untuk mempermudah orang lain, baik dalam berkomunikasi ataupun mendengarkan secara detail apa yang diucapkan seseorang. Alat ini biasanya disambungkan dengan perangkat-perangkat lainnya.

Kata earphone masuk ke dalam bagian dari sifat eksosentris karena tidak ada unsur baik dari kata ear maupun phone yang berfungsi sebagai unsur yang diterangkan maupun menerangkan.

c) Jatuh Cinta

Komposisi atau kata majemuk jatuh cinta merupakan komposisi atau kata majemuk yang terdiri atas dua kata, yaitu jatuh yang berarti sikap atau gerakan turun (sudah sampai) ke tanah, atau permukaan lainnya. Kata jatuh sendiri juga dapat diartikan sebagai suatu kondisi, seseorang yang tidak lagi berada di posisi yang tinggi, atau pun di atas; menjadi (sakit, miskin, cinta, dan sebagainya) (Depdiknas, 2012). Sedangkan, kata cinta adalah perasaan seseorang yang mengalami hal yang begitu menyenangkan, rasa suka yang teramat, bisa juga menunjukan sikap terpikat antara lawan jenis, dan sejenisnya; suka sekali; sayang benar (Depdiknas, 2012). Maka, kata jatuh cinta memiliki arti sebuah perasaan menyenangkan, rasa ingin memiliki, terpikat, dan lain-lain itu ia taruh kepada orang lain. Komposisi atau kata majemuk ini tidak memiliki unsur yang menerangkan, dan juga diterangkan, maka ia masuk ke dalam kelompok sifat eksosentris.

d) Luar Kepala

Komposisi atau kata majemuk luar kepala, memiliki dua kata yang terdiri atas kata 'luar' yang berarti bukan dari bagian, lingkungan, daerah, atau tempat itu sendiri (Depdiknas, 2012). Sementara, kata kepala memiliki arti sebagai bagian tubuh teratas, yang posisinya berada tepat di atas leher, juga dapat diartikan sebagai suatu bagian utama yang biasanya memimpin atau mengatur suatu kelompok (Depdiknas, 2012). Maka, komposisi atau kata majemuk luar kepala diartikan sebagai hal yang sudah tercatat dalam ingatan (tidak perlu dicatat ataupun dituliskan). Komposisi atau kata majemuk, baik 
dari kata luar maupun kepala itu sendiri tidak memiliki unsur untuk diterangkan maupun menerangkan.

e) Malam Minggu

Komposisi atau kata majemuk malam minggu terdiri atas dua kata yaitu kata malam yang berarti suatu kondisi matahari yang telah terbenam dan langit sudah gelap, dihiasi bulan dan bintang (Depdiknas, 2012). Sedangkan, kata minggu berarti hari pertama dalam jangka waktu seminggu, biasanya ditandai dengan kalender yang berwarna merah, hari waktu untuk berlibur ataupun bersantai dari serangkaian aktivitas yang telah dijalani; hari pertama dalam jangka waktu satu minggu; Ahad (Depdiknas, 2012). Maka, komposisi atau kata majemuk malam minggu diartikan sebagai hari atau malam menjelang hari berikutnya (di sini berarti menjelang hari minggu).

Komposisi atau kata majemuk ini tidak memiliki unsur yang diterangkan maupun menerangkan, baik dari kata malam maupun kata minggu itu sendiri.

f) Membekali Diri
Komposisi atau kata majemuk membekali diri memiliki kata dasar bekal diri, yang terdiri atas dua kata yaitu bekal yang berarti sesuatu yang disediakan dan dapat digunakan selama perjalanan, berupa makanan, uang, dan lain sebagainya. Bisa juga diartikan sebagai sesuatu yang dapat dipergunakan kelak apabila perlu, seperti ilmu pengetahuan (Depdiknas, 2012). Sementara, kata diri berarti seorang atau tunggal, tidak dengan yang lain; orang seorang (terpisah dari yang lain); badan (Depdiknas, 2012). Maka, ketika kedua kata tersebut dilekatkan menjadi komposisi atau kata majemuk bekal diri atau membekali diri, berarti ia mempersiapkan atau menyediakan apa yang diperlukannya, baik untuk perjalanan (dalam bentuk makanan, uang, dan lain sebagainya), maupun hidupnya (dalam bentuk ilmu pengetahuan) untuk dirinya sendiri.

g) Pengharum Ruangan

Komposisi atau kata majemuk pengharum ruangan terdiri atas dua kata, yaitu kata pengharum yang berarti sesuatu yang untuk mengharumkan, menghilangkan bau 
tidak sedap, dan tidak enak, atau kata lainnya adalah pewangi (Depdiknas, 2012). Sedangkan, kata 'ruangan' adalah tempat yang terletak di berbagai tempat seperti kamar, kelas, maupun di dalam kapal, dan sebagainya. Maka, komposisi atau kata majemuk pengarum ruangan dapat diartikan sebagai alat atau sesuatu yang dipergunakan untuk membuat suatu tempat menjadi enak untuk dihirup aromanya, meninggalkan aroma yang nyaman, atau untuk menghilangkan bau tidak sedap.

h) Sudut Hati

Komposisi atau kata majemuk sudut hati terdiri atas dua kata, yaitu kata sudut yang berarti kondisi suatu bangunan yang dibuat oleh dua garis yang saling berpotongan, di sekitar titik potongnya (Depdiknas, 2012). Sementara, kata hati memiliki arti sebagai organ di dalam tubuh manusia yang berwarna kemerahmerahan, yang berdebar-debar, juga kadang dianggap sebagai tempat menenyimpan segala bentuk batin dan perasaan. Maka, komposisi atau kata majemuk sudut hati, dapat diartikan sebagai suatu kondisi seseorang yang menyimpan batin atau perasaannya, di tempat yang paling tak terlihat, atau jauh dari penglihatan, dalam arti kiasan.

i) Tempat Tidur

Komposisi atau kata majemuk tempat tidur terdiri atas dua kata, yaitu kata tempat yang berarti sesuatu atau bidang yang berfungsi, atau juga digunakan sebagai penyimpanan (menaruh barang, dan lain sebagainya). Sedangkan, kata tidur dapat diartikan sebagai suatu kondisi seseorang tidak sedang melakukan aktifitas apapun, dengan mata terpejam, dan tubuh serta kesadarannya dalam keadaan berhenti. Maka, komposisi atau kata majemuk tempat tidur dapat diartikan sebagai bidang atau ruang untuk mengistirahatkan diri, komposisi atau kata majemuk tempat tidur dapat juga diartikan sebagai kasur atau ranjang.

j) Terima Kasih

Komposisi atau kata majemuk terima kasih terdiri atas dua kata, yaitu kata terima yang berarti mendapatkan atau memperoleh sesuatu hal. Sementara, kata kasih yang berarti perasaan atau rasa sayang, cinta, atau suka kepada seseorang atau diri sendiri. Maka, 
komposisi atau kata kata majemuk dari terima kasih dapat diartikan sebagai, ungkapan atas rasa syukur kepada seseorang, atau bentuk penghormatan atas apa yang telah diberikan orang lain kepada kita, dan kita terima.

k) Tumbuh Besar

Komposisi atau kata majemuk tumbuh besar terdiri atas dua kata, yaitu kata tumbuh yang berarti hidup, bertambah ukuran atau bentuknya, menjadi lebih dari sebelumnya, juga bisa diartikan sebagai sedang berproses. Sedangkan, kata besar memiliki arti lebih dari ukuran sedang, atau tidak pada ukuran umumnya, bisa juga sebagai bentuk kiasan dari orang atau sifat yang berkuasa. Maka, komposisi atau kata majemuk tumbuh besar dapat diartikan sebagai kondisi seseorang atau sesuatu yang sedang berproses, dari bentuk sebelumnya (yang kecil ataupun sedang), menjadi lebih dari ukurannya.

\subsection{Sifat Endosentris}

Sementara, komposisi atau kata majemuk yang bersifat endosentris, yaitu komposisi atau kata majemuk yang memiliki atau terdiri atas unsur yang menjadi inti gabungan. Maksudnya adalah salah satu katanya berfungsi sebagai unsur yang menerangkan (M), dan kata lainnya berfungsi sebagai unsur yang diterangkan (D). Maka, data yang telah diklasifikasikan dalam tabel di atas yang memiliki sifat endosentris adalah sebagai berikut.

a) Adik Bungsu

Komposisi atau kata majemuk adik bungsu terdiri atas kata adik yang berarti saudara kandung, kerabat, atau sapaan kepada lakilaki ataupun perempuan yang lebih muda. Sementara, kata bungsu berarti yang terakhir, yang termuda, ataupun paling muda dibandingkan yang lainnya. Maka, komposisi atau kata majemuk adik bungsu dapat diartikan sebagai seseorang (saudara, kerabat, atau sapaan kepada laki-laki maupun perempuan), yang terkecil, termuda, atau paling muda di antara kelompok atau bagiannya.

Komposisi atau kata majemuk adik bungsu ini masuk ke dalam sifat endosentris, disebabkan ada unsur yang diterangkan dan menerangkan dalam katanya, yaitu 
kata adik yang diterangkan oleh kata bungsu yang menerangkannya.

b) Air Mata

Komposisi atau kata majemuk air mata terdiri atas kata air yang berarti cairan jernih yang tidak berwarna, tidak berasa, dan tidak berbau yang diperlukan dalam kehidupan para makhluk hidup. Sedangkan, kata mata berarti salah satu bagian dari indra yang berfungsi untuk melihat, dapat juga diartikan sebagai bagian yang tajam pada alat pemotong. Maka, komposisi atau kata majemuk air mata dapat diartikan sebagai kondisi atau ungkapan kesedihan, dengan mengalirkan atau mengeluarkan cairan dari dalam mata.

Komposisi atau kata majemuk air mata ini merupakan bagian dari sifat endosentris karena adanya kata yang memiliki unsur diterangkan dan menerangkan pada katanya, yaitu terletak pada kata air yang diterangkan oleh kata mata yang menerangkannya.

c) Air Putih

Komposisi atau kata majemuk air putih terdiri atas kata air yang berarti cairan jernih yang tidak berwarna, tidak berasa, dan tidak berbau yang diperlukan dalam kehidupan para makhluk hidup. Sementara, kata putih berarti warna dasar yang serupa dengan kapas, murni, suci atau tidak ternodai. Maka, komposisi atau kata majemuk air putih adalah cairan bening atau jernih, yang tidak berwarna, tidak berasa, dan tidak berbau yang dapat diminum tanpa atau sudah melalui serangkain proses terlebih dahulu.

Komposisi atau kata majemuk air putih bersifat endosentris, karena adanya kata yang memiliki unsur diterangkan dan menerangkan, yang terletak pada air yang diterangkan oleh kata putih yang menerangkannya.

d) Bau Bayi

Komposisi atau kata manjemuk bau bayi terdiri atas kata 'bau' yang berarti sesuatu atau apa-apa saja yang ditangkap oleh indra penciuman (berupa anyir, harum, busuk, dan lain sebagainya). Sedangkan, kata bayi yang berarti anak yang belum lama lahir, atau anak yang baru saja dilahirkan oleh seorang wanita yang sudah mengandung. Maka, komposisi atau kata majemuk bau bayi dapat diartikan sebagai aroma khas yang 
dihasilkan oleh seorang bayi, yang biasanya memiliki aroma yang wangi.

Komposisi atau kata majemuk bau bayi masuk ke dalam bagian dari sifat endosentris, disebabkan ada kata yang memiliki unsur yang diterangkan dan menerangkan, yaitu terletak pada kata bau yang menerangkan kata bayi yang diterangkan.

e) Bus Malam

Komposisi atau kata majemuk bus malam terdiri atas kata 'bus' yang berarti kendaraan atau angkutan umum, beroda empat, atau lebih, dengan ukuran yang besar, dan dapat mengangkut atau memuat banyak orang (penumpang). Sementara, kata malam berarti suatu kondisi matahari yang telah terbenam, dan langit sudah gelap, dihiasi bulan dan bintang. Maka, komposisi atau kata majemuk bus malam dapat diartikan sebagai kendaraan atau angkutan umum, yang hanya beroperasi atau khusus di malam hari (saat matahari sudah terbenam) saja.

Komposisi atau kata majemuk bus malam bersifat endosentris karena terdapat kata yang memiliki unsur diterangkan dan menerangkan, yaitu terletak pada kata bus yang diterangkan oleh kata malam yang menerangkan.

f) Cacar Air

Komposisi atau kata majemuk cacar air terdiri atas kata cacar yang berarti penyakit kulit yang disebabkan oleh virus. Sedangkan, kata air yang berarti cairan jernih yang tidak berwarna, tidak berasa, dan tidak berbau yang diperlukan dalam kehidupan para makhluk hidup. Maka, komposisi atau kata majemuk cacar air dapat diartikan sebagai penyakit kulit yang disebabkan oleh virus, yang mengandung air didalamnya.

Komposisi atau kata majemuk cacar air ini, di kelompokan ke dalam sifat endosentris karena adanya kata cacar sebagai unsur yang diterangkan, oleh kata air sebagai unsur yang menerangkan.

g) Mencium Aroma

Komposisi atau kata majemuk mencium aroma memiliki kata dasar cium aroma. Kata cium berarti permukaan bibir bersentuhan dengan sesuatu hal atau permukaan lainnya. Sementara, kata aroma adalah bau-bauan yang harum, 
bersifat atau mengandung hal tertentu. Maka, komposisi atau kata majemuk mencium aroma dapat diartikan sebagai hal atau sikap dalam menerima bau-bauan yang harum, atau bersifat (mengandung hal) tertentu, baik disengaja maupun tidak.

Komposisi atau kata majemuk mencium aroma masuk ke dalam kelompok sifat endosentris, karena adanya unsur kata mencium yang menerangkan unsur kata 'aroma' yang diterangkan.

h) Memakan Waktu

Komposisi atau kata majemuk memakan waktu memiliki kata dasar makan waktu yang terdiri atas kata makan yaitu adalah memasukkan sesuatu ke dalam mulut, kemudian mengunyah dan menelannya. Sedangkan, kata waktu berarti seluruh rangkaian (lamanya) proses ketika kita melakukan perbuatan, keadaan, ataupun sesuatu yang sedang berlangsung. Maka, komposisi atau kata majemuk memakan waktu dapat diartikan sebagai suatu hal yang memerlukan waktu banyak, atau hal yang dilakukan dengan banyak sekali waktu yang diperlukan.
Komposisi atau kata majemuk memakan waktu masuk ke dalam sifat endosentris, karena adanya kata memakan yang berperan sebagai unsur yang menerangkan kata waktu yang berperan sebagai unsur yang diterangkan.

i) Membaca Pikiran

Komposisi atau kata majemuk membaca pikiran memiliki kata dasar baca pikiran. Kata baca berarti melihat serta memahami isi dari suatu hal yang ditulis, dalam bentuk lisan maupun hanya dalam hati saja. Sementara, kata pikiran berarti adalah hasil yang didapat, akal, atau ingatan dalam upaya kita melakukan suatu hal. Maka, komposisi atau kata majemuk membaca pikiran dapat diartikan sebagai kemampuan seseorang, untuk mengetahui apa yang sedang dipikirkan oleh orang lain.

Komposisi atau kata majemuk membaca pikiran masuk ke dalam sifat endosentris karena adanya unsur diterangkan dan menerangkan, pada kata memakan yang berfungsi untuk menerangkan kata waktu yang diterangkan.

j) Penutup Istimewa 
Komposisi atau kata majemuk penutup istimewa terdiri atas kata penutup yang berarti pengunci atau suatu bagian akhir dari serangkain peristiwa atau hal. Sedangkan, kata istimewa berarti suatu hal yang khas, atau lain dari pada yang lain. Maka, komposisi atau kata majemuk penutup istimewa, dapat diartikan sebagai bagian akhir dari suatu peristiwa yang bentuk atau sifatnya lain dari yang lain, atau begitu khas.

Komposisi atau kata majemuk penutup istimewa masuk ke dalam kelompok sifat endosentris, karena adanya kata penutup yang memiliki unsur diterangkan oleh kata istimewa yang memiliki unsur menerangkan.

\section{k) Piring Berisi}

Komposisi atau kata majemuk piring berisi terdiri atas kata piring yang memiliki arti wadah berbentuk bundar pipih, dan sedikit cekung, tempat untuk meletakkan sesuatu seperti makan. Sementara, kata berisi memiliki kata dasar isi yang merupakan sesuatu yang ada, termuat, terkandung di dalam suatu benda, atau suatu hal, dan lain sebagainya. Maka, komposisi atau kata majemuk piring berisi, diartikan sebagai wadah yang terdiri atas berbagai macam hal, berupa isian seperti makanan, nasi, cemilan, dan lain sebagainya.

Komposisi atau kata majemuk piring berisi, adalah kompisisi atau kata majemuk yang bersifat endosentris, karena mengandung unsur kata 'piring' yang diterangkan oleh 'berisi' yang merupakan unsur kata yang menerangkan.

1) Saku Celana

Komposisi atau kata majemuk saku celana terdiri atas kata saku yang berarti kantong, atau tempat kecil yang biasanya sengaja dibuat untuk meletakkan sesuatu (benda kecil, yang tidak terlalu besar atau muat) di dalamnya. Sedangkan, kata celana adalah pakaian luar yang nenutupi area pinggang hingga mata kaki, terkadang hanya sampai lutut, yang membungkus tungkai kaki secara terpisah. Maka, komposisi atau kata majemuk saku celana, dapat diartikan sebagai tempat untuk menaruh sesuatu, benda, atau benda kecil yang muat dalam pakaian celana, atau kantong yang memang didesain khusus untuk celana, agar berfungsi sebagaimana pengertian dari kata saku itu sendiri. 
Komposisi atau kata majemuk saku celana merupakan bagian dari sifat endosentris, disebabkan kata saku yang memiliki unsur menerangkan kata celana yang diterangkan.

\section{Simpulan}

Berdasarkan hasil analisis data, disimpulkan bahwa temuan penelitian ini berupa bentuk komposisi yang ditemukan sebanyak 23 data. Data tersebut didapatkan dalam petikan kata dan frasa dalam novel "Pengantar Tidur Panjang”. Unsur tersebut didapatkan 10 data yang bersifat eksosentris dan 13 data yang bersifat endosentris.

\section{Daftar Pustaka}

Basyarudin. (2015). KATA MAJEMUK BAHASA INDONESIA SUATU KAJIAN LINGUISTIK TRANSFORMASIONAL

GENERATIF. BAHAS, 26 (2). https://doi.org/https://doi.org/10.24 114/bhs.v26i2.5549

Chaer, A. (2008). Morfologi Bahasa Indonesia: Pendekatan Proses. Jakarta: Rineka Cipta.

Departemen Pendidikan Nasional. (2012). Kamus Besar Bahasa Indonesia: Edisi Keempat. Jakarta: PT Gramedia Pustaka Utama.

Fauziah. (2018). Proses morfologis dalam Bahasa Melayu Dialek Pontianak. Jurnal Pendidikan Dan Pembelajaran Khatulistiwa, 7 (2), 179-193.

http://jurnal.untan.ac.id/index.php/j pdpb/article/view/23998/18804

Fauziyah, S. W. (2020). Kata Majemuk Dalam Teks Berita Daring Cnn International Edisi September 2019: Kajian Morfologi. Suar Betang, 15 (1), 35-44. https://doi.org/10.26499/surbet.v15 i1.143

Kusumawardhani, P. (2015). the Analysis of Morphology in Writing an English Narrative Composition. Wanastra: Jurnal Bahasa Dan Sastra, 7 (1), 32-40.

Mahsun. (2012). Metode Penelitian Bahasa. Jakarta: Raja Grafindo Persada.

Mulyono, I. (2013). Morfologi Teori dan Sejumput Problematik Terapannya. Bandung: Yramawidya.

Octarini, E. R., Laksana, I. K. D., \& Widarsini, N. P. N. (2017). Proses Pembentukan Kata dalam Kumpulan Cerpen 1 Perempuan 14 Laki-Laki Karya Djenar Maesa Ayu. Humanis: Journal of Arts and Humanities, 20 (1), 75-82. https://doi.org/https://doi.org/10.24 843/JH.2017.v20.i01

Putri, M. H. (2014). KATA MAJEMUK NOMINA DALAM KORAN KOUGAKU EDISI 1 JUNI 2011. Jurnal Mahsiswa Fakultas Ilmu Budaya, 7 http://jimbastrafib.studentjournal.u b.ac.id/index.php/jimbastrafib/artic le/view/762 
Ramlan, M. (2001). Morfologi: Suatu Tinjauan Deskriptif. Yogyakarta: CV. Karyono.

Rohmadi, D. (2012). Morfologi: Teknik Morfem dan Kata. Surakarta: Yuris Pustaka.

Simpen, I. W. (2017). Dinamika Pembentukan Kata Bahasa Indonesia. RETORIKA: Jurnal Ilmu Bahasa, 1 (2 SE-Articles), 319-330. https://doi.org/10.22225/jr.1.2.37.3 19-330

Sudaryanto. (2015). Metode dan Teknik Aneka Teknik Analisis Bahasa: Pengantar Penelitian Wahana Kebudayaan Secara Linguistis. Yogyakarta: Universitas Sanata Dharma.

Verhaar, J. W. (2010). Asas-asas Linguistik Umum. Yogjakarta: Gadjah Mada University Press. 
Analisis Komposisi dalam Cerpen... 